\title{
A Feasibility Study of NIR Spectra in Identifying Heavy Metal Contamination in Rice Around Abandoned Tailing Ponds: A Case Study in Guiyang County in South China
}

Ren Hongyan *, Zhuang Dafang, Yang Junxing and Yu Xinfang

State key laboratory of resources and environmental informaiton system, Institute of geographic sciences and natural resources research, CAS, 11A, Datun Road, Chaoyang District, Beijing, China

\begin{abstract}
Protecting people from heavy metal contamination is an important public-health concern and a major national environmental issue in China. The purpose of this study is to explore the feasibility of the near-infrared (NIR) spectral technique in identifying heavy metal concentration (HMC) in coarse rice. 28 rice samples were gathered from the farmlands around four tailing ponds in Guiyang County of south China, and then were sieved by $2.0 \mathrm{~mm}$ plastic mesh for the laboratory spectral measurement and the determination of protein, lead $(\mathrm{Pb})$, and copper $(\mathrm{Cu})$. Before constructing the partial least square regression (PLSR) models for predicting HMC, all spectral data were treated by some methods, including, logarithm (Log), baseline correction (BC), standard normal variate (SNV), multiple scatter correction (MSC), first derivates (FD), and continuum removal (CR). In terms of enrichment coefficients (EC), $\mathrm{Pb}$ was accumulated in rice at a high level (17.05). Its relation to protein $(P=0.77, r<0.01)$ is more significant than that of $\mathrm{Cu}(P=0.67, r<0.01)$. Protein content was well predicted by MSC-PLSR model with higher coefficient of determination $\left(R^{2}=0.51\right)$ and lower root mean square error (RMSE $=0.17 \%)$. MSC-PLSR models were respectively built for $P b\left(R^{2}=0.49, R M S E=2.01 \mathrm{mg} / \mathrm{kg}\right)$ and $\mathrm{Cu}\left(\mathrm{R}^{2}=0.29, \mathrm{RMSE}=0.75 \mathrm{mg} / \mathrm{kg}\right)$. It is feasible to identify $\mathrm{Pb}$ and $\mathrm{Cu}$ content in rice by using NIR spectral technique. However, further investigation should be conducted on the application of spectral technique in discriminating the other heavy metals in crops due to the limitations of few samples and particle size interruption.
\end{abstract}

\section{Keywords: NIR spectra; Rice; Lead; Copper}

\section{Introduction}

Food contamination caused by environmental pollution is more and more serious in China, which resulted in the concerning on public health and transferring food security from food quantity to food quality. In China, farmland about 10 per cent of the total cultivated land was polluted due to environmental pollution, which caused more than 12 million tons of grain contaminated by heavy metal [1]. Therefore, if no effective monitoring and control measures, China's food security will result in serious public health problems.

In food grain, organic ingredients such as protein and carbohydrates are rich in a variety of various hydrogen group, like $\mathrm{OH}, \mathrm{CH}, \mathrm{NH}, \mathrm{SH}$ and $\mathrm{PH}$. They have special spectral absorption in the region from 1000$2500 \mathrm{~nm}$, which is the main information for the quick determination of grain protein and amylase content via near-infrared spectral technique [2-4]. Most of the heavy metals are spectrally featureless so that spectral responses could not be directly used for the assessment of heavy metals in rice. With a close combination of protein, crude fiber, and other ingredients, heavy metals present significant correlation with protein in rice [5]. In present, detection of heavy metal concentration (HMC) in grain is mostly realized by physical and chemical methods that can exactly obtain concentration of heavy metal; however, it is timeconsuming, cumbersome, and inefficient. On the basis of the hypothesis that HMC could be spectrally estimated through the correlation between HMC and protein contents, the objectives of this study are to: 1) build quantitative model for the quick prediction of both heavy metal and protein content, and 2) to evaluate the feasibility of near-infrared spectroscopy in assessing HMC in coarse rice.

\section{Methods}

In total, twenty-eight rice samples were gathered from study area, located in a valley across two hills in Guiyang suburb periphery to the Baoshan Mine, and were then put into plastic bags before removing the rice glumes by means of physical methods. Mechanical grinder (FZ-102, Tianjin) was used for crushing rice to coarse flour, and then crushed samples were sieved by plastic meshes $(2.0 \mathrm{~mm})$.

Kjeldahl method was used for determination of protein content in coarse rice [6], while the concentrations of Lead $(\mathrm{Pb})$ and Copper $(\mathrm{Cu})$ were respectively measured by an atomic fluorescent spectrophotometer (AFS-2202, Beijing Kechuang Haiguang Instrument Co., Ltd., China).

Contamination caused by single metal was assessed by enrichment coefficient, according to the following formula [7]

\section{$\mathrm{Pi}=\mathrm{G} / \mathrm{S}$}

Where $G$ is the measured value of metal $i$ and $S$ is the criteria for metal $i$ authorized by national standards (GB2715-2005 and GB151991994). With lower value than $1, P_{i}$ indicates that coarse rice is not polluted by metal $i$ and safe for public health. Otherwise, it denotes that coarse rice is contaminated.

Under the laboratory condition, reflectance spectra of coarse rice were gathered by a mobile spectrometer (Analytical Spectral Devices Inc., USA) with a spectrum from $350 \mathrm{~nm}$ to $2500 \mathrm{~nm}$. Each sample was scanned 10 times and the average was chosen. All spectral data were

*Corresponding author: Hongyan Ren, State key laboratory of resources and environmental information system, Beijing 100101, China, Tel: +86-010-64 859 025; E-mail: renhy@igsnrr.ac.cn

Received June 11, 2013; Accepted September 17, 2013; Published September 22, 2013

Citation: Hongyan R, Dafang Z, Junxing Y, Xinfang Y (2013) A Feasibility Study of NIR Spectra in Identifying Heavy Metal Contamination in Rice Around Abandoned Tailing Ponds: A Case Study in Guiyang County in South China. J Geophys Remote Sensing 2: 112. doi:10.4172/2169-0049.1000112

Copyright: (c) 2013 Hongyan R, et al. This is an open-access article distributed under the terms of the Creative Commons Attribution License, which permits unrestricted use, distribution, and reproduction in any medium, provided the original author and source are credited. 
Citation: Hongyan R, Dafang Z, Junxing Y, Xinfang Y (2013) A Feasibility Study of NIR Spectra in Identifying Heavy Metal Contamination in Rice Around Abandoned Tailing Ponds: A Case Study in Guiyang County in South China. J Geophys Remote Sensing 2: 112. doi:10.4172/21690049.1000112

Page 2 of 3

smoothed by the Savitzky-Golay filter with a second-order polynomial fit. Finally, spectrum from $1000 \mathrm{~nm}$ to $2500 \mathrm{~nm}$ was reserved and employed for analysis.

The smoothed and resampled spectral data were pre-treated with some methods, including logarithm (Log), baseline correction (BC), standard normal variate (SNV), multiplicative scatter correction (MSC), first derivates (FD), and continuum removal (CR). The pre-treatments of the near-infrared spectral data were achieved with Unscrambler 9.7 (CAMO ASA, Norway). Continuum removal was completed with IDL/ ENVI 4.2 (ESRI Ltd., USA).

For all 28 samples, cross-validation of leave-one-out method was used to verify the prediction capability of the partial least square regression (PLSR) models for the training set. The parameter root mean square error (RMSE) was used to evaluate the prediction results. Coefficients of determination $\left(R^{2}\right)$ were calculated for reliability of prediction. PLSR models were also achieved with Unscrambler 9.7.

\section{Results and Discussion}

As shown in Table 1, average of $\mathrm{Pb}$ and $\mathrm{Cu}$ concentration in coarse rice is $3.41 \mathrm{mg} / \mathrm{kg}$ and $2.92 \mathrm{mg} / \mathrm{kg}$, respectively. Concentrations of both $\mathrm{Pb}$ and $\mathrm{Cu}$ are significantly correlated with protein content. At the significance level of 0.01 , concentration of $\mathrm{Pb}$ is more closely correlated with protein content than that of $\mathrm{Cu}$. Content of protein in coarse rice $(5.03 \%)$ is lower than average value (9.5\%) [8], which is related to potential depression caused by heavy metal contamination. According to the enrichment coefficients given in Table 1, there was no obvious $\mathrm{Cu}$ contamination $(\mathrm{Pi}=0.29)$ but serious $\mathrm{Pb}$ pollution $(\mathrm{Pi}=17.15)$ in this region. As a toxic element, $\mathrm{Pb}$ in rice would be harmful to public health when local people intake these $\mathrm{Pb}$-polluted rice over a long period of time, which is widely known to make blood lead exceed the standard and especially cause developmental problems in children. Local authorities should pay much attention to protecting residents from these foods.

There is obvious absorption at the wavebands including $1150 \mathrm{~nm}$, $1400 \mathrm{~nm}, 1750 \mathrm{~nm}, 1900 \mathrm{~nm}$, and $2100 \mathrm{~nm}$, as shown in Figure 1a. Peak values of reflectance spectra are respectively located at the wavebands such as $1300 \mathrm{~nm}, 1650 \mathrm{~nm}, 1800 \mathrm{~nm}, 2000 \mathrm{~nm}$, and $2200 \mathrm{~nm}$

According to the correlation coefficients (solid line curve in Figure $1 b)$, spectral reflectance with peak values is more closely correlated with protein contents than that of the rest wavebands, although the correlation is not significant enough due to some interruptions like particle size of crushed grains. Eliminating effects of multiple scattering, MSC pre-treatment reduced the effects of variable particle size on the spectral reflectance to some degree, which improved the correlation between protein contents and spectral reflectance in the region from 1000 to $2500 \mathrm{~nm}$ (dot-dashed curve in Figure 1b).

\begin{tabular}{|c|c|c|c|}
\hline & Protein $(\%)$ & $\mathrm{Cu}(\mathrm{mg} / \mathrm{kg})$ & $\mathrm{Pb}(\mathrm{mg} / \mathrm{kg})$ \\
\hline Range & 1.56 & 3.85 & 6.25 \\
\hline Min & 4.18 & 1 & 0.15 \\
\hline Max & 5.74 & 4.85 & 6.4 \\
\hline Mean & 5.03 & 2.92 & 3.41 \\
\hline \multirow[t]{2}{*}{ Std. Dev } & 0.42 & 1.03 & 1.59 \\
\hline & \multicolumn{3}{|c|}{ Enrichment coefficients } \\
\hline \multirow[t]{2}{*}{$\mathrm{Pi}$} & & 0.29 & 17.05 \\
\hline & \multicolumn{3}{|c|}{ Correlation between $\mathrm{HMC}$ and protein content } \\
\hline Protein & & $0.67\left({ }^{* *}\right)$ & $0.77\left({ }^{* *}\right)$ \\
\hline
\end{tabular}

${ }^{* *}$ Correlation is significant at the 0.01 level (2-tailed).

Table 1: Descriptive statistics of protein content and HMC in coarse rice.
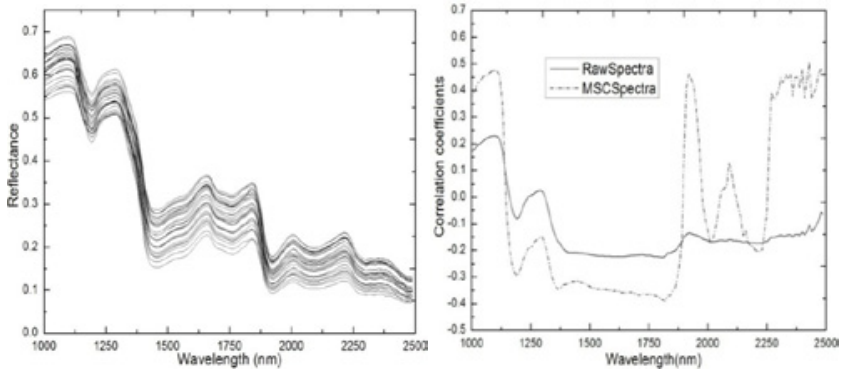

Figure 1: a) Spectral reflectance curve of coarse rice $(1000-2500 \mathrm{~nm}) ;$ b) Correlation between spectral reflectance (Raw and MSC spectra) and protein content.

\begin{tabular}{|l|l|l|l|l|l|l|l|l|}
\hline & Raw & CR & BC & FD & Log & Inverse & MSC & SNV \\
\hline $\begin{array}{l}\text { Principal } \\
\text { components }\end{array}$ & 10 & 5 & 14 & 11 & 14 & 1 & 7 & 8 \\
\hline RMSE & 0.12 & 0.19 & 0.06 & 0.01 & 0.26 & 0.38 & 0.17 & 0.12 \\
\hline R $^{2}$ & 0.17 & 0.22 & 0.27 & 0.37 & 0.11 & 0.03 & $0.51\left(^{* *}\right)$ & $0.50\left(^{* *}\right)$ \\
\hline
\end{tabular}

Units of RMSE are \%; **Correlation is significant at the 0.01 level (2-tailed).

Table 2: PLSR models constructed by full spectral wavebands for Protein Content $(\mathrm{PC})$ of coarse rice.

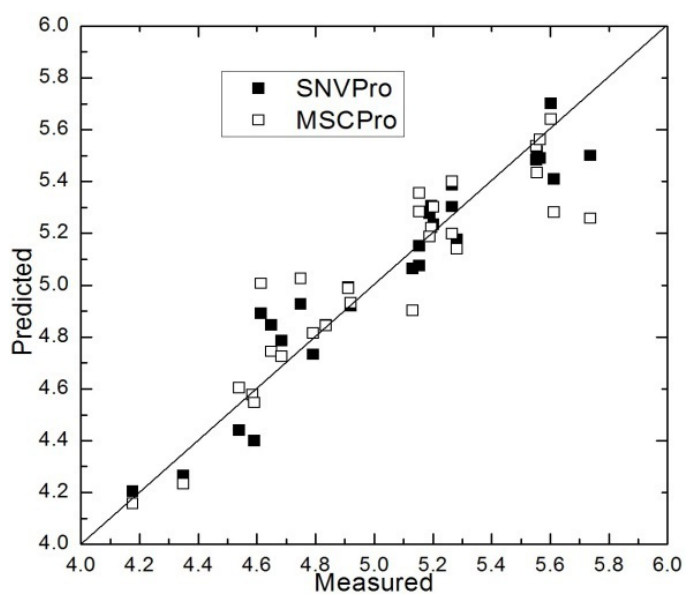

Figure 2: Plot of protein content predicted against measured by PLSR model with spectra of MSC and SNV.

Parameters of PLSR models based on all the pre-treatment (Raw, CR, BC, FD, Log, Inverse, MSC, and SNV) were listed in Table 2. In terms of higher $\mathrm{R}^{2}$, less principal components, and less RMSE, MSCPLSR and SNV-PLSR models yielded better prediction of protein contents. Meanwhile, MSC-PLSR performed slightly better than SNVPLSR model in the light of higher $\mathrm{R}^{2}$ and more points of locating nearby the 1:1 line, as shown in Figure 2. We speculated that MSC is more suitable for predicting protein content in coarse rice than SNV because of MSC's well-reducing effects of particle size of crushed rice, and that particle size of rice samples is one important interruption on spectral reflectance. Therefore, MSC spectra were employed to build the PLSR model for predicting $\mathrm{Pb}$ and $\mathrm{Cu}$ concentration in coarse rice.

Based on the significant correlation between heavy metal and protein, MSC-pretreated reflectance spectra of coarse rice were employed to build PLSR models for predicting $\mathrm{Pb}$ and $\mathrm{Cu}$ concentrations. 
Citation: Hongyan R, Dafang Z, Junxing Y, Xinfang Y (2013) A Feasibility Study of NIR Spectra in Identifying Heavy Metal Contamination in Rice Around Abandoned Tailing Ponds: A Case Study in Guiyang County in South China. J Geophys Remote Sensing 2: 112. doi:10.4172/21690049.1000112

Page 3 of 3
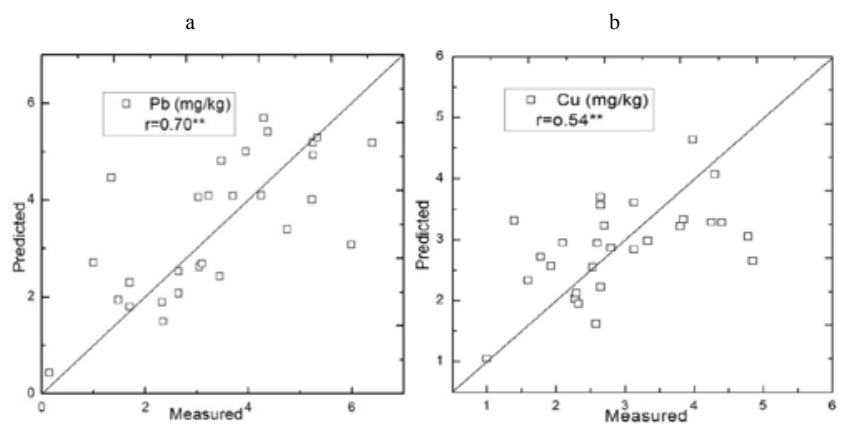

Figure 3: Plots of measured HMC against predicted by PLSR models with MSC-pretreated spectra.

Comparison of predicted $\mathrm{Pb}$ and $\mathrm{Cu}$ concentrations to measured values was illustrated for these two predicting models (Figures $3 \mathrm{a}$ and $3 \mathrm{~b}$ ). Prediction accuracy of $\mathrm{Pb}$ concentration $\left(\mathrm{R}^{2}=0.49, \mathrm{RMSE}=2.01 \mathrm{mg} /\right.$ $\mathrm{kg})$ is better than that of $\mathrm{Cu}\left(\mathrm{R}^{2}=0.29, \mathrm{RMSE}=0.75 \mathrm{mg} / \mathrm{kg}\right)$, which is equal to the comparison of $\mathrm{Pb}$-Protein $(r=0.77, P<0.01)$ to $\mathrm{Cu}$-protein correlation $(r=0.67, P<0.01)$. However, prediction accuracy of $\mathrm{Pb}$ and $\mathrm{Cu}$ concentration in this study is to be improved. In the future, some appropriate solutions including gathering more rice samples, grinding and sieving rice by more aperture meshes, and covering many more types of rice, could be taken to improve the stability and accuracy of prediction models. Although applicability of this method needs to be further evaluated through experiments on the other trace elements such as $\mathrm{Cd}$ and As in rice, our results proved the hypothesis that HMC could be spectrally estimated through the correlation between HMC and protein contents, and indicated that near-infrared spectroscopy is an alternative solution to quickly and effectively predict HMC in rice.

\section{Conclusion and Recommendation}

Despite of low $\mathrm{Cu}$ concentration, rice samples were seriously contaminated by $\mathrm{Pb}$, which would be greatly harmful to public health of local residents. We suggest that the department concerned should take some effective measures to control relative pollution so as to protect local people from heavy metal contamination in foods. On the basis of correlation between HMC and protein contents, near-infrared spectroscopy could be employed as an alternative solution to quickly assess HMC in rice. In the future, effects on the prediction accuracy of HMC through this method should be further studied. Furthermore, appropriate spectral indices, derived from canopy spectra of paddy plants at the crucial stages, would be tried to predict HMC in rice at the mature stage.

\section{References}

1. Li Y (2011) Soil contamination and toxicity in China. China Economic Weekly. Special issues $21^{\text {st }}$ February.

2. Miryeong S, Franklin EB, Anna MM, Elaine TC (2004) Near-infrared spectroscopy for determination of protein and amylose in rice flour through use of derivatives. Cereal Chem 81: 341-344.

3. Delwiche SR, McKenzie KS, Webb BD (1996) Quality characteristics in rice by near-infrared reflectance analysis of whole grain milled samples. Cereal Chem 73: $257-263$.

4. Windham W, Lyon BG, Champagne ET, Franklin E Barton, Bill D Webb, et al. (1997) Prediction of Cooked Rice Texture Quality Using Near-Infrared Reflectance Analysis of Whole-Grain Milled Samples. Cereal Chem 74: 626632.

5. Yang JR, ZhaY, Liu H (1999) The distribution and chemical forms of Cd, Cu and $\mathrm{Pb}$ in polluted seeds. China Environmental Science 19: 500-504.

6. Su JP, Hou CY (2005) Comparison and analysis on determining methods towards protein in rice. Food Science and Technology 6: 78-81.

7. Dong JH, Yu M, Chen W, Ge DM, Li KX (2010) Safety of heavy metals pollution for wheat planted in reclaimed mining soil. Transactions of the CSAE 26: 280 286.

8. Zhou LH, Liu QQ, Zhang CQ, Xu Y, Tang SZ, et al. (2009) Variation and distribution of seed storage protein content and composition among different rice varieties. Acta Agronomica Sinica 35: 884-891. 